\title{
Regulatory foundations of financialisation: May Day, Big Bang and international banking
}

$1975-1990^{1}$

Catherine Schenk

Oxford University

From the 1970 s to the 1990 s there was a revolution in international financial markets, which combined the processes of financialisation and globalisation. Deregulation and financial innovation were the two underlying forces that facilitated this transformation. At the same time distinctive national characteristics of banking structures and cultures influenced the way that financial globalisation affected the geographic distribution of financial activity. This article addresses these seismic shifts through three perspectives: changes in regulation and the geographic pattern of international banking activity, reform of the main stock markets in New York and London and the rise of financial conglomerates. It identifies complementarity as well as competition among international financial centres.

Keywords: financialisation, globalization, deregulation, international financial centres, financial conglomerates

JEL codes: G15,G28, G34, N20, N40

C. Schenk, Professor of Economic and Social History, St. Hilda's College, Oxford University, Cowley Place, Oxford, OX4 1DY, UK ; email: catherine.schenk@history.ox.ac.uk.

\footnotetext{
${ }^{1}$ I am grateful for the excellent research assistance of Wilfried Kisling and Raphael Heim and support from HERA JRP Uses of the Past funded by the European Commission and the AHRC.
} 
The interactions between finance, society, culture and the economy have been key preoccupations of Cassis' work across his career. In the early 1980s, as observers began to identify the second globalisation, Cassis (1984/1994) began to explore the development of London as an international financial centre during the era of the first globalisation in the late $19^{\text {th }}$ century. He then expanded his scope to the continental European financial centres throughout the $20^{\text {th }}$ century (Cassis 1991, Cassis and Telesca 2018). In so doing he focused on the culture of international banking as well as the regulatory and institutional frameworks. This paper follows in this tradition by addressing the cultural as well as regulatory aspects of conglomeration in the second great globalisation in the late $20^{\text {th }}$ century.

In the 1980 s the structure of international banking and finance changed profoundly in interlinked processes later dubbed financialisation and globalisation. These concepts both remain somewhat fuzzy, crossing sociology and politics as well as economics.

Financialisation is used here to describe the economic tilt towards financial markets both in terms of size, diversity, compensation and innovation. Thus, the proliferation of financial products and trading, the rising importance of the activities of banks and non-bank financial firms relative to the economies in which they operated, and the spread of financial activity to non-financial firms are characteristics of financialisation (Roy and Willett 2018, Krippner 2011, Epstein 2018, Lin and Tomosovic-Devey 2010). The definition of globalisation is also highly contested and can be discipline specific (Robinson 2004) but at its simplest, it reflects a commonality of influences across a broad geographic scope, created by the integration of markets and societies through ever faster information technologies and communications. By the early 1990s, Helleiner (1994, p. 295) remarked that finance was 'the sector of the world 
economy where "globalization" is most developed", reflecting not only the size of crossborder financial flows but also the simultaneity and constancy of markets connected through ICT. Predictions of the demise of the nation-state due to financial globalisation have not been fulfilled, but deregulation and regulatory competition was certainly a facilitating factor for both of these processes. Financial globalisation changed the relationship between states and financial markets, with profound effects on the structure of the international banking and the nature of international financial centres, as well as for social and political systems (Davis and Kim 2015, Epstein 2005) and prompted models of a political trilemma that suggested globalisation, national democracy and national policy sovereignty are incompatible (Rodrik 2011, Bordo and James 2019). Nevertheless, the persistence of national characteristics of banking markets, inertia in the location of international financial centres and the national basis of most banking regulation and supervision speaks to the enduring importance of local as well as global forces.

As Cassis has noted, 'while there is some continuity with the previous period, globalisation having started in the 1960s, there was unquestionably a break around 1980' (Cassis 2006, p. 242). He thus reminds us that the foundations for this revolution were set in earlier decades. In the US, the dramatic increase in commercial paper as interest rates rose from the mid-1960s reduced the role of banks as a source of industrial credit (Rhoades, 1983) at the same time as the offshore Eurodollar market matured in London (Battilossi, 2002). From 1973, the collapse of the Bretton Woods pegged exchange rate system prompted corporate demand for treasury services and products to respond to new market and operational risks arising from fluctuating exchange and interest rates (Strange 1986, Schenk 2017). Syndicated bank lending to sovereign borrowers surged after the 1973/74 oil crisis (particularly to developing economies) and created a new stream of management fee 
income for banks. The change in the structure of national and international banking at the end of the Bretton Woods era in 1973 was therefore profound, and set the foundations for the financial globalization of the 1980s.

Cassis has particularly contributed to the history of international financial centres as the locus of the distribution of global capital. From this perspective, the impact of changes in financial markets in the 1970 s and 1980 s on the geographical distribution of financial activity was complex. On the one hand, the conglomeration of financial services in large 'bulge bracket' firms increased the gravity of leading centres such as New York and London, and made these institutions more difficult to supervise. On the other hand, this period saw the dispersal of international banking to offshore markets through subsidiaries in small island economies with favourable tax and regulatory environments (Palan et al 2013, Schenk 2020a). While the literature on international financial centres is often framed in terms of competition or league tables, it is clear that the restructuring of the market also encouraged greater complementarity and cooperation between the two great poles of London and New York (Schenk 2002). Most important financial institutions had branches and subsidiaries in both centres to reap their distinctive advantages: the large size of the US market and London's agglomeration of services and proximity to Europe. As a result, while American investment banks and universal banks dominated, London persisted as a centre for international banking and finance.

This article addresses these seismic shifts through three perspectives. The next section examines changes in regulation and the geographic pattern of international banking activity. This is followed by a discussion of the reform of the main stock markets in New York and 
London that prompted restructuring of financial institutions in the 1980s. The third section addresses the renewal of deregulation and the rise of financial conglomerates.

In the US, the relationship between the state and the banking system was challenged almost continuously through the post-war period as American banks struggled against the constraints of the Glass-Steagall Act, introduced in the wake of the 1929 stock market crash to insulate investment banking from commercial retail banking. The lesser known 1956 Bank Holding Company Act stopped companies with multiple banks from combining banking with other financial services, but excluded holding companies that had only one bank. From the mid-1960s, this loophole was used to avoid Federal regulation by setting up single bank holding companies that were then able to acquire or establish non-bank financial subsidiaries. By 1970 about one-third of US deposits were held by banks in single bank holding companies, twice as much as held by the regulated multi-bank holding companies (Hayes 1971). To close the loophole, the Nixon administration amended the Act at the end of 1970 to include single-bank holding companies, but exempted holding companies who had already used the loophole by mid-1968, thus protecting incumbents. In addition, under Section 4(c) (8) the Federal Reserve Board could allow holding companies to engage in business 'closely related to' banking where the Fed considered there was a public interest. This opened up room for interpretation by the Federal Reserve Board, although a major change was not evident until the late 1980s, as discussed below.

In the UK, the move to increase external and internal competition came earlier. In the 1950s commercial banks enjoyed a cosy cartel in which they agreed not to compete for 
deposits through interest rates and they cooperated with the Treasury to direct bank lending to promote economic growth (Kynaston 2011, Capie 2010). London's merchant banks were reinvigorated by the advent of the Eurodollar market from the early 1960s, but their market share was quickly eroded by the invasion of US and European banks to take advantage of the Eurodollar and Eurobond markets (Battilossi 2002). Competition and Credit Control in 1971 introduced domestic competition for commercial banks from quasibanks, including hire purchase companies (Needham 2014, Moran 1986). This deregulation quickly led to a crisis in 1973 when several fringe banks found themselves illiquid or insolvent after an asset market correction, drawing both the Bank of England and clearing banks into providing support (Reid 1982, Capie 2010). Despite the cost of the crisis, and recognition of systemic vulnerability, progress to enhance supervision was slow. The ambitious (Wilson) Committee to Review the Functioning of Financial Institutions was launched in 1977 and began to gather evidence, but only reported finally in 1980. More tangibly, the 1979 Banking Act finally formalised the statutory role of the Bank of England in the supervision of the banking system.

In the international context, the shudder in cross-border banking in 1974 due to fraud and market instability prompted the launch of the Committee on Banking Regulations and Supervisory Practices at the Bank for International Settlements to enhance exchange of best practice and reduce loopholes in national regulation of the international banking system (Schenk 2017). But progress was slow until the 1980s (Goodhart 2010). The view of the Committee's chairman, George Blunden (from the Bank of England) in 1977, was that The banking system of a country is central to the management and efficiency of its economy; its supervision will inevitably be a jealously guarded national 
prerogative. Its subordination to an international authority is a highly unlikely development, which would require a degree of political commitment which neither exists nor is conceivable in the foreseeable future (Bank of England 1977, p. 326).

Nevertheless, the apparatus (that became the Basel Committee) for international cooperation on banking supervision was in place.

By the end of the 1970s, therefore, substantial changes had occurred both in tightly regulated New York and in relatively relaxed London, which set the foundation for innovation and expansion over the following decades and increased the complementarity between the two centres. The constraints on activity and barriers to entry into investment banking in New York helped to promote the City of London as an international financial centre. These features also set the stage for a break between the nationality of institution and the location of financial activity.

As Cassis (2002) highlighted, persistent structural differences between national banking systems are important for how international financial centres developed. Figure 1 shows the rising value of domestic deposit bank assets relative to the overall size of the economies of the US, UK and Germany. The growth was particularly striking for the UK and Germany while the US banks' assets grew more in line with the US economy as a whole. The higher value in Germany in the 1970 s reflects the bank dominated credit system in Germany compared to the market-based system in the UK and the reliance on commercial paper in the US. The German system also remained more tightly regulated both on a national basis and against foreign participation than either New York or London. It was not until 1984/5 that the Bundesbank liberalised the $25 \%$ withholding tax on bond income for non-resident 
participation and began to allow more money market products like certificates of deposit (Cassis 2006, pp. 246-47). Figure 1 also shows that in the USA non-bank financial institutions' assets grew much faster than bank assets in the 1980s and 1990s, demonstrating the financialisation of the economy (consistent data are not available for the Germany and the US).

Figure 1

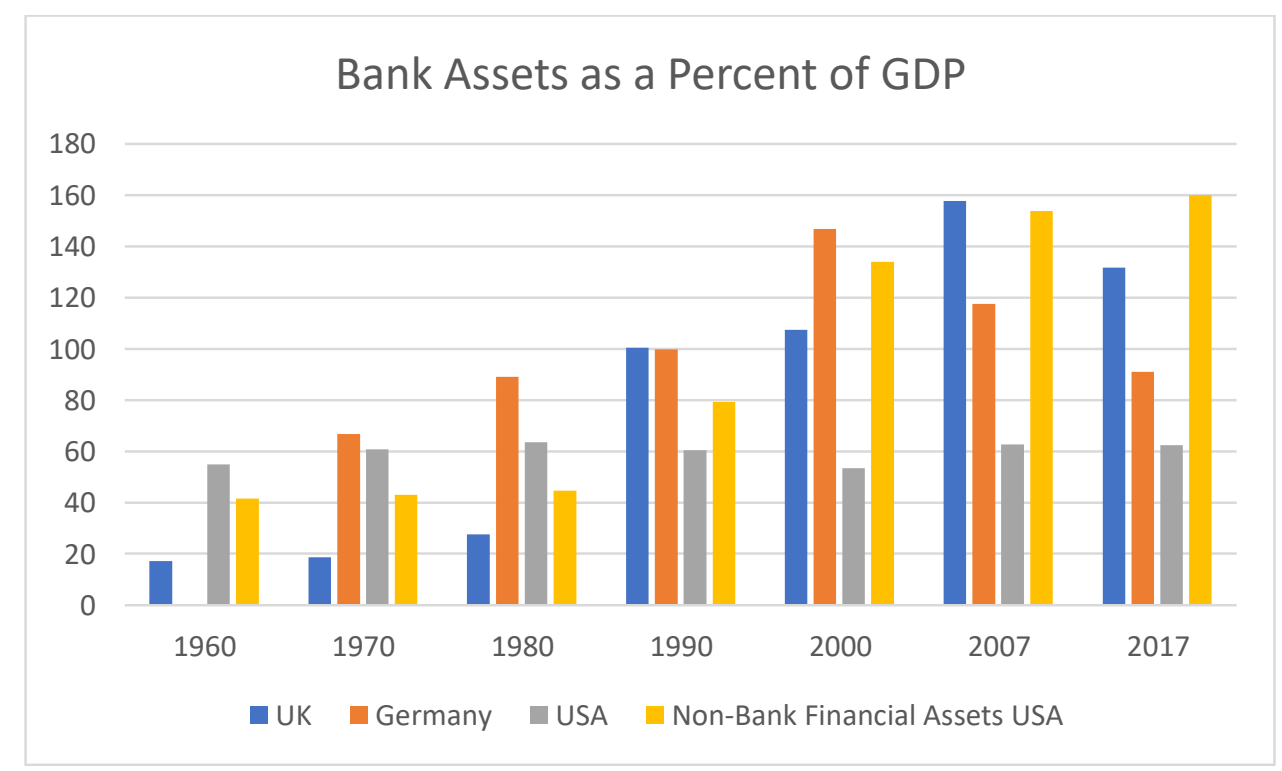

Source: Global Financial Development Database (GFDD), The World

Bank.https://databank.worldbank.org/reports.aspx?source=global-financial-development\#

In international banking and financial markets, US banks surged into London to evade their domestic constraints in the 1960s and 1970s and by 1983 US banks held over a quarter of all cross-border claims of financial institutions, compared with about $6 \%$ each for the German and the British (BIS). Despite the leading position of American banks, London remained the dominant international banking centre, hosting over a quarter of cross border bank claims in 1983. This was about the same amount as the five main island offshore centres combined. In December 1981 the US Fed launched offshore International Banking Facilities (IBF) in 
several US centres to capture more of the offshore dollar business from the Caribbean, and they did attract more international banking assets, but by 1990 less than 10 per cent of cross border claims were located in the US. ${ }^{2}$ The combined dominance of American banks and the City of London became a defining feature of the culture of investment banking where English was the lingua franca and the nexus between The City and Wall Street was the main fulcrum for the globalisation of finance.

The transformation of international finance in the 1970 s and 1980 s was profoundly affected by changes in securities markets and this section compares the reforms of stock markets in London and New York. Since the $19^{\text {th }}$ century, London had been the most international equity market in the world in terms of company listings while New York mainly served its large domestic market (Michie 1999). But in the 1980s, there were serious disruptions caused in part by trans-Atlantic competition. In both centres, the attack on traditional selfregulation of the stock markets was based in claims that the system was anti-competitive and protected incumbents to the disadvantage of customers through fixed minimum commissions. In each case, the threat of external interference and third-party encroachment on stock exchange franchises prompted internal reviews by the stock exchanges themselves. In London, additional pressure for reform became apparent as the London Stock Exchange (LSE) fell behind its much larger rival in New York. From 1975 to 1985 the turnover on stock markets in the UK fell from $25 \%$ of the value of that of the US to merely $5 \%(\mathrm{WDI}) .^{3}$ The outcome of similar reforms (albeit 10 years apart) had a similar

\footnotetext{
${ }^{2}$ IBFs allowed US banks to make loans to and attract deposits from non-resident individuals and banks free from reserve requirements and with favourable tax treatment.

${ }^{3}$ World Development Indicators. Valuation in US\$.
} 
impact on customers, but there were differential effects on the structure of the industry because of the contrasting regulatory frameworks in the US and the UK. This section reviews May Day in 1975 in New York and Big Bang in 1986 in London.

In the US, the elimination of fixed commission followed a Securities and Exchange Commission (SEC) investigation report in January 1975 in the context of several years of falling commission revenue and a decline in the number of securities firms (SEC 1975). The formal exchange was also under pressure from competitors; from 1967 to 1973 over-thecounter trading doubled from 3.3\% to $7 \%$ of the value traded on the NYSE (SEC 1974). Nevertheless, the principle of fixed minimum commission (dating from 1792) was strongly defended by members of the NYSE (Johnson and McLauchlin 2006, Jorden 1975). An important consideration was the purpose of commission and how it related to costs. Institutional investors resented paying the same commission for their large trades as for smaller trades. There were clearly economies of scale that meant that the costs for a large trade should be significantly different from a small trade (SEC 1974, pp. 39-40). A related issue was that the fixed commission included both the costs of the research underlying advice from brokers as well as the practical execution of trades on behalf of customers. ${ }^{4}$ The lack of market competition meant that the actual costs of research vis-à-vis execution were not transparent and indeed would vary across different classes of customer and product with inevitable cross-subsidisation. On the basis of its review, the SEC decided to eliminate fixed commission from 1 May 1975.

\footnotetext{
${ }^{4}$ There is an analogy to the MiFid II rules introduced in 2018 to unbundle payment for research and execution by asset managers on behalf of customers.
} 
The immediate impact was an increase in market turnover, but the impact on commissions was more complex. At the start of June 1975, the Commissioner of the SEC, Philip A. Loomis, noted that considerable discounting had followed from May Day as midsized and smaller brokerage firms sought to increase their market share, although the main beneficiaries were large institutional investors rather than individual investors (Loomis 1975). ${ }^{5}$ Rates for institutional investors like pension funds and insurance companies fell from 25 cents per share to 8 cents (Wayne 1985). But the benefits did not filter down to individual investors; they could access discount brokers providing only execution, but the cost of full brokerage services increased from on average 30 cents per share to $40-42$ cents (Wayne 1985). The end of fixed commission thus benefited institutional investors at the cost of individuals.

The May Day reform also affected market structure. With lower margins, companies had to rely on scale to generate revenues and this favoured large firms rather than smaller brokers. Many partnerships were bought out by larger firms, generating huge fortunes for their owners. ${ }^{6}$ Large firms also sought to replace commission income by offering a wider range of more complex financial products. In 1974 commissions accounted for nearly 50 percent of broker securities firms but by 1976 this had already dropped to $41 \%$ and by 1980 to one third. Revenue from trading on the other hand increased from $14 \%$ in 1974 to $22 \%$ by $1980 .^{7}$

Over the following decade, securities firms were also affected by the rapid growth in both equity and debt markets. The corporate debt market benefited from economic growth in

\footnotetext{
${ }^{5}$ Competitive commission rates were already in place for trades over $\$ 300,000$.

${ }^{6}$ Partnerships fell from about one quarter of securities firms to 16\% in New York City from 1974 to 1981. Securities Exchange Commission Annual Report, various issues.

${ }^{7}$ Securities Exchange Commission Annual Report, various issues.
} 
the USA, a switch from loans to bond issues for many mid-sized firms, and then the explosion of high yield junk bonds associated with the wave of leveraged buy-outs that followed the Tax Reform Act of 1986 (Jefferis 1990). The surge in leveraged corporate finance that followed has been described as a 'financial mania' that culminated with KKR's hostile take-over of RJR Nabisco and the collapse of Drexel Burnham Lambert at the end of the decade (McCauley et al 1999, p.3). The transformation of American corporate finance attracted the world's attention to Wall Street, but this drama was mainly a domestic American story. London remained a crucial financial centre for Eurobonds, foreign exchange and M\&A. At the same time, the restrictions on bank holding companies described in the previous section constrained the consolidation of banks with other financial institutions in New York for another 10 years.

For the first five years, the reforms in New York had a limited impact on the London Stock Exchange's (LSE's) customers because of exchange controls, but in 1979 Margaret Thatcher's Conservative Government finally abandoned the last UK exchange controls and British investors had free access to the New York market to trade British and international securities. While the volume of share trading in New York surged ahead of London, the LSE stubbornly clung to its traditional ways and fixed commission, protecting incumbent members. Brokers had to go through market intermediaries (jobbers) in order to ensure that customers received/paid a genuine market price. The restrictions on commission and exclusive membership of the LSE meant that foreign firms increasingly traded outside the exchange for their institutional clients. Like the NYSE in the 1970s, the LSE thus faced competitive forces within London as well as from beyond. 
On 27 October 1986, Big Bang signified a dramatic and abrupt new direction for the London. For the first time, brokers were able to compete on price rather than abiding by the fixed commissions set by Stock Exchange Rule Book. This seemingly minor adjustment had far reaching effects: the end of the separation of brokers and jobbers, a new IT trading platform, and lifting the rules that had excluded foreign companies from the exchange. Figure 2 shows the dramatic increase in the turnover in London at the time of the reform.

Figure 2

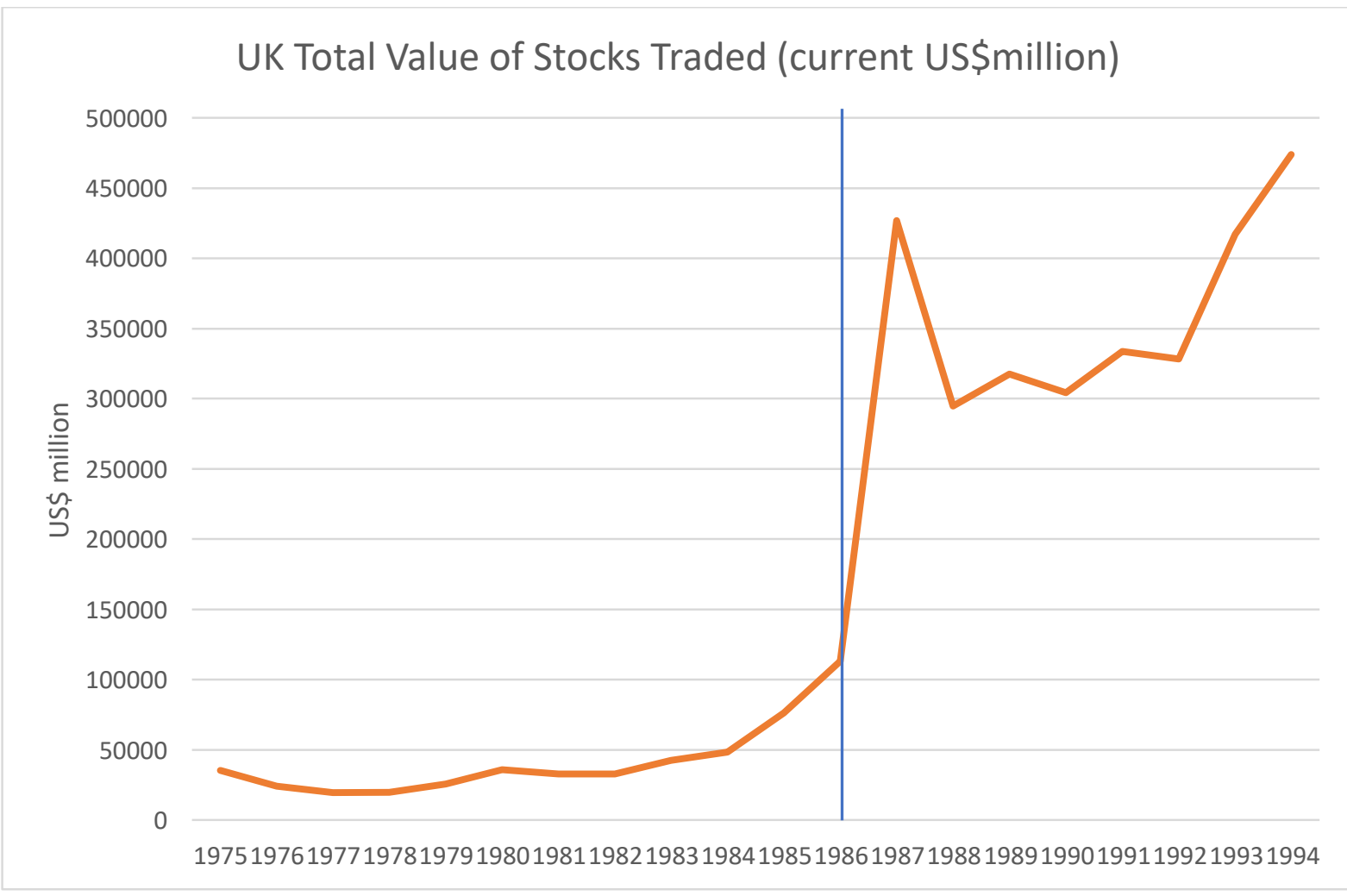

Source: World Development Indicators.

Big Bang seemed an almost instant success and has since been viewed as the saviour of the City of London as Europe's leading financial centre. Nigel Lawson, Chancellor of the Exchequer during 1986, later claimed that "Without [Big Bang], it is doubtful if London would have retained its place as Europe's pre-eminent financial centre, and certain that it would not 
have become the foremost truly international financial centre of the modern globalised economy that it is today, to the great benefit of the British economy as a whole' (Lawson, 2006). But looking more closely, the revolution in the market seems less dramatic and less impactful - less of a shocking 'Bang' and more an adaptation to longer term forces. Cassis emphasised the antecedents to this innovation, describing Big Bang 'more like a culmination' of reforms over 20 years than 'a starting point' (Cassis 2006, p. 246). Moreover, the surge in turnover in 1986 was not restricted to London and indeed was dwarfed by the growth in the US markets. Figure $\mathrm{x}$ shows that Big Bang marked a partial reversal of the trend of relative decline but that turnover then settled at 5-10 per cent that of the US.

Figure 3

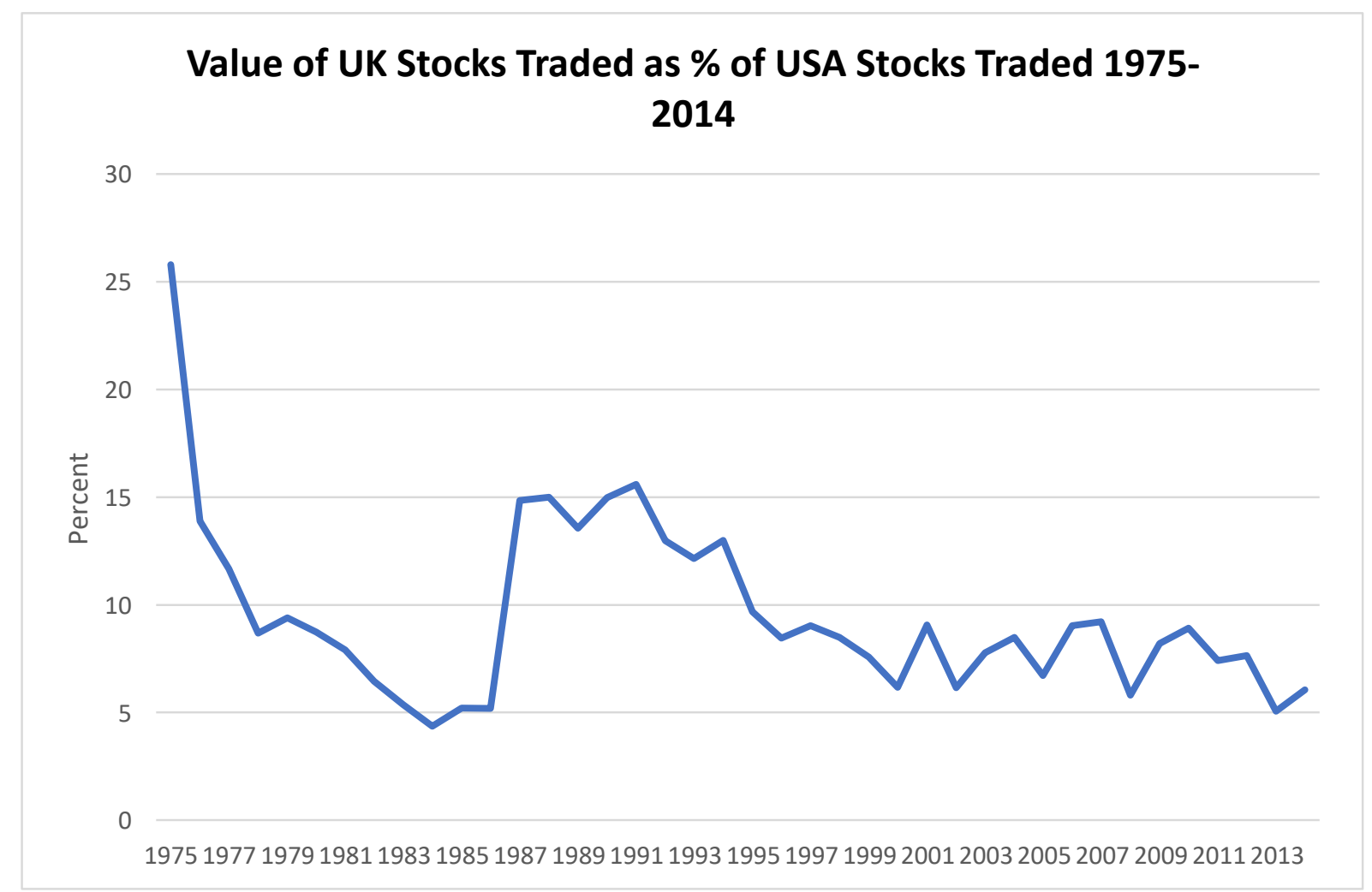

Source: World Development Indicators. 
So, what was Big Bang and how did it affect securities trading in London and the competitiveness of London compared to New York as an international financial centre? Michie (1999) has provided the most comprehensive historic treatment based on interviews and contemporary accounts. By 1979, there was a variety of British interests pushing for reform. The Bank of England wanted greater competition in the gilt market, which had reduced to only 2-3 jobbers controlling $70-80 \%$ of the market. Margaret Thatcher's Conservative government, elected in May 1979, was enthusiastically also strongly in support of an agenda of increasing market competition in all sectors of the economy, including financial services. They also embraced the return of nationalised assets to the general public through privatization, for which the public needed cheaper and easier access to the stock market (Billings and Wilson 2019). Edwards (2016) highlighted the inconsistencies in the notion of a 'shareholding democracy' in the process of privatisation, and hostility within the financial services sector to providing costly services to individual share owners, but by the 1970s the Conservative Party's agenda for privatization in part required the reinvigoration of public share ownership.

Fortunately, the means to overcome the LSE's closed system had been laid down by the previous Labour Government's agenda to promote consumer interests. The 1973 Fair Trading Act extended existing anti-monopoly rules to the services sector and in 1976 a Restrictive Practices Court was set up to test and enforce open competition across the economy. In October 1976 Labour's Secretary of State for Trade, Edmund Dell, announced plans to reassess the regulation of the securities market, with a view to introducing legislation over insider trading and new supervisory roles for the Department of Trade and for the Bank of England. In response, the Bank of England drew interested parties together into a Council for the Securities Industry in March 1978 as a way to bolster the self- 
regulation of the exchange and deflect external supervision. ${ }^{8}$ In October 1978 the Chairman of the LSE indicated that the rule book would not be changed to combine brokers and jobbers, but he sought alternatives to having to come before the Restrictive Practices Court over fixed commission. Months of negotiation ensued.

In February 1979, Gordon Borrie, the Director-General of Fair Trading, finally referred the LSE Rule Book to the Restrictive Practices Court. The LSE objected and sought to be exempted, and there was some disagreement within the incoming Conservative government (elected in May). Geoffrey Howe as Chancellor of the Exchequer worried more about disruption to the market from referring the LSE while John Nott was strongly opposed to an exemption for the LSE. From the start, Thatcher was 'inclined to agree with Mr. Nott' but kept an open mind. ${ }^{9}$ Gradually, however, Nott's arguments about improving competition and overcoming the LSE's restrictive practices won out over Howe's concerns about disrupting the market. Bellringer and Michie (2014) argue convincingly that the initial decision not to exempt the LSE was down to Conservative MP and former Secretary of Defence, Nott, who was especially exercised by the lack of competitiveness of the City. In November 1979 the Chair of the LSE, Nicholas Goodison, complained to Thatcher that

I was really astonished by the Government's failure to respond to our repeated requests for discussions before the taking of an adverse decision. As you know, I am a keen supporter of your Government. I am very sorry that I had to criticise it publicly for taking this decision without any consultation whatever with us. I had no choice, which was a very invidious position to find myself in. ${ }^{10}$

\footnotetext{
${ }^{8}$ The Council for the Securities Industry; Press Criticism, 19 May 1978. BoE 7A11-1.

${ }^{9}$ Note by T.P. Lankester, 4 June 1979. TNA PREM19/1005.

${ }^{10}$ Letter NP Goodison to PM M. Thatcher, 6 November 1979. TNA PREM19/1005.
} 
Thatcher responded that there had been 'an extensive exchange of views' with the Bank of England and ministers and that Nott had warned Goodison prior to the announcement. ${ }^{11}$ Relations between the government and the LSE were clearly strained.

For almost 4 years, the LSE continued to lobby for exemption, spending $£ 1.5$ million according to some reports, albeit without the full support of all of its members. ${ }^{12}$ Nott did not stand for parliament in the election of June 1983 and the way was clear for the new Secretary of State for Trade and Industry, Cecil Parkinson, the new Chancellor of Exchequer Nigel Lawson and the new Bank of England Governor, Robin Leigh-Pemberton to return to the case to exempt the LSE from the Court process. ${ }^{13}$ By mid-July the government was ready to consider exemption to avoid disrupting the markets both for equities and government debt, but Borrie as Director General of Fair Trading strongly resisted. ${ }^{14}$ The government suggested a compromise under which the LSE would agree to change its rules in return for not going through the court system. This would include ending fixed commission and relaxing the barriers to membership. Goodison reluctantly got agreement in principle from the LSE council and the decision on whether to exempt the LSE went to the Cabinet in late July $1983 .{ }^{15}$ The discussion balanced 'the need to avoid disturbance in the securities market against the risk that Ministers may be accused of favouring City interests and of inconsistency with their general policy of seeking to promote competition and to get rid of restrictive practices' ${ }^{16}$ The next day, Parkinson announced in Parliament that the LSE had agreed to gradually liberalise commissions and include lay members on its Council with the

\footnotetext{
11 Letter Thatcher to Goodison 20 November 1979. TNA PREM19/1005.

12 Draft statement by W. Greenwell and Co., 16 September 1983. BoE 15A91-4. Michie $(1999,547)$ estimates the cost in May 1983 as $f 1.2$ million.

${ }^{13}$ Letter Cecil Parkinson to PM M. Thatcher, 12 July 1983. TNA PREM/1005.

14 Memo for PM M. Thatcher, 15 July 1983. TNA PREM19/1005.

15 Note of a meeting with Goodison, 20 July 1983. TNA PREM19/1005.

${ }^{16}$ Memo on Cabinet discussions for PM M. Thatcher, 25 July 1983. TNA PREM19/1005.
} 
intention of broadening its membership, and in return the LSE would be exempted from the restrictive practices court (Michie 1999: 550-52). But the government and the LSE continued to insist on the separation of brokers and jobbers in order to protect customers' interests.

In the ensuing months, behind the scenes discussion among the LSE, DTI, Treasury and Bank of England tried to clarify what impact the end of fixed commission would bring and whether the separation of operations would be feasible under these new circumstances (Bellringer and Michie 2014). Gradually, it became clear that with no minimum commission, the separation would not be sustainable. Bank of England staff predicted that falling incomes would prompt consolidation among brokers in London even if the separation of jobbers was retained after minimum commission was abandoned. They were also concerned about the discipline of self-regulation and the liquidity of the gilt market if 'large and powerful foreign banks and securities houses' entered the market by injecting capital into LSE members. ${ }^{17}$ Already there had been considerable consolidation among jobbers because of their greater reliance on capital reserves. ${ }^{18}$ The LSE Council finally confirmed its part of the deal at an Extraordinary General Meeting of the members of the LSE on 11 October 1983 where they agreed to abandon fixed commission within 3 years. The clock was ticking for reform of the market, but there was plenty of time to adapt.

With fixed commission now bound to disappear, the separation of brokers and jobbers seemed unsustainable, and the market responded with a rush of mergers and acquisitions as members of the LSE sought fresh capital and non-members positioned themselves for a lowering of barriers to entry. In 1982 the limit on outside ownership of members of the LSE

\footnotetext{
17 'Ownership of the UK Securities Industry', 26 September 1983. BoE 19A91-4.

${ }^{18}$ In 1983 there were 17 jobbers compared to 100 in 1960.
} 
had been lifted from $10 \%$ to $29.9 \%$, to allow the relatively small British firms to access more capital. The first operation under the new rule was US bank Security Pacific taking up the maximum interest in the London broker Hoare Govett as soon as the new limit was applied in October 1982 (Michie 1999, p. 555). After the confirmation in 1983 that fixed commissions would end, many more banks and other financial firms bought stakes in London brokers and jobbers, often on the understanding that a larger stake could be acquired as soon as the $29 \%$ ceiling was lifted. In 1986 , London merchant banks alone acquired stakes in 11 brokers and 3 jobbers, while 22 foreign institutions acquired stakes in 26 brokers and 1 jobber. As in New York, this consolidation often also marked a shift from partnerships to public companies, which shifted the burden of risk from owner-managers to shareholders. There were concerns about the management challenges posed by this restructuring and also about the ability to supervise complex financial institutions and the potential for fraud. ${ }^{19}$

Figures 4 and 5 below show the number and distribution of acquisitions in the run up to Big Bang: most targeted firms before and during Big Bang were brokers and most acquiring firms were banks. Moreover, while 1986 marked a peak of this activity, the process of consolidation began at least two years beforehand and continued afterward, driven mainly by insurance companies and larger financial groups. Other opportunities also drove conglomeration in the 1980s: Corporate IPOs, the wave of pending privatizations across Europe, interest rate volatility and the surge in bond market trading all increased demand for investment banking services. The European White Paper on completing the internal market

\footnotetext{
${ }^{19}$ See discussion in PREM19/1718.
} 
published in 1985 signalled the looming single market in 1992 and financial institutions sought to position themselves for this new world.

Figure 4

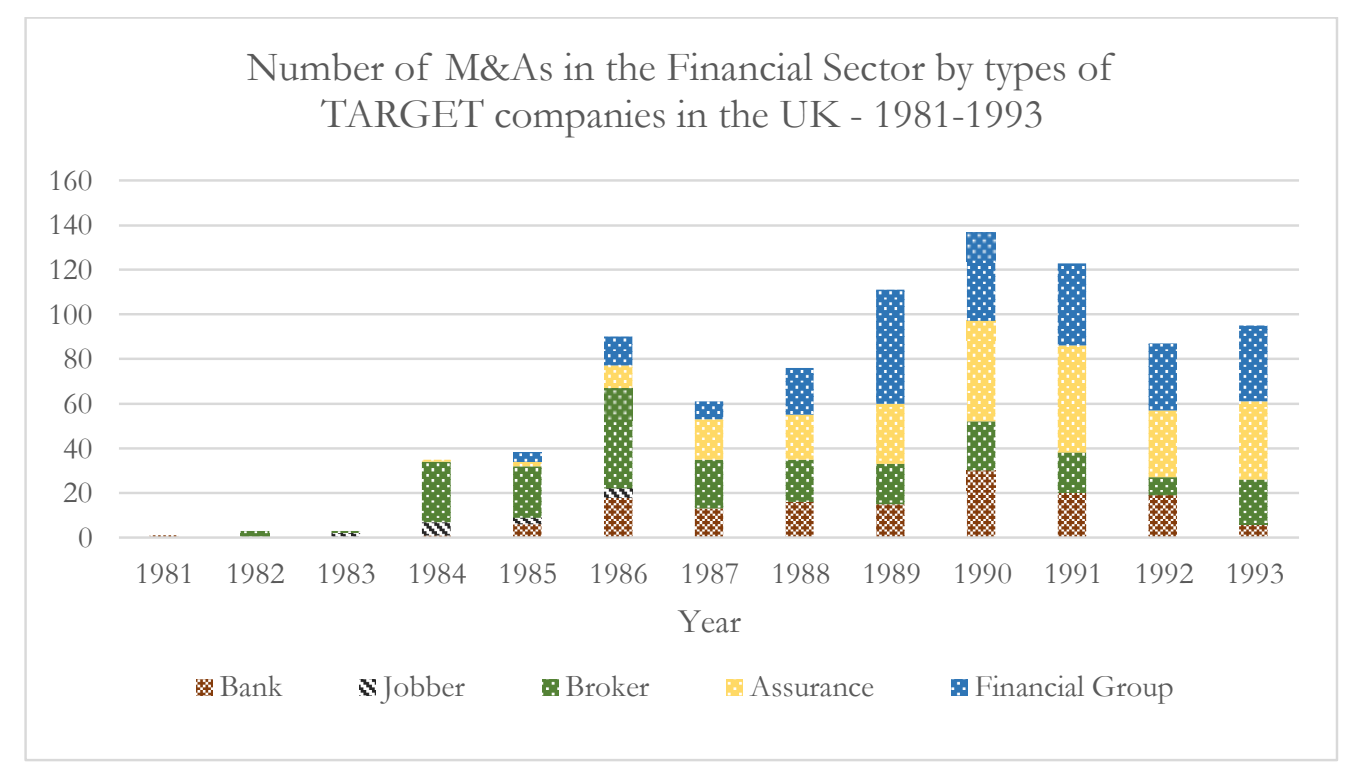

(Walter, 2004) Appendix 1; Euromoney, October 1985; International Financing Review, 'Big Bang 1986: A Revolution in UK Securities and Investment Banking'; Thomson Reuters - Eikon - M\&A of Financial Institutions in the UK.

Figure 5

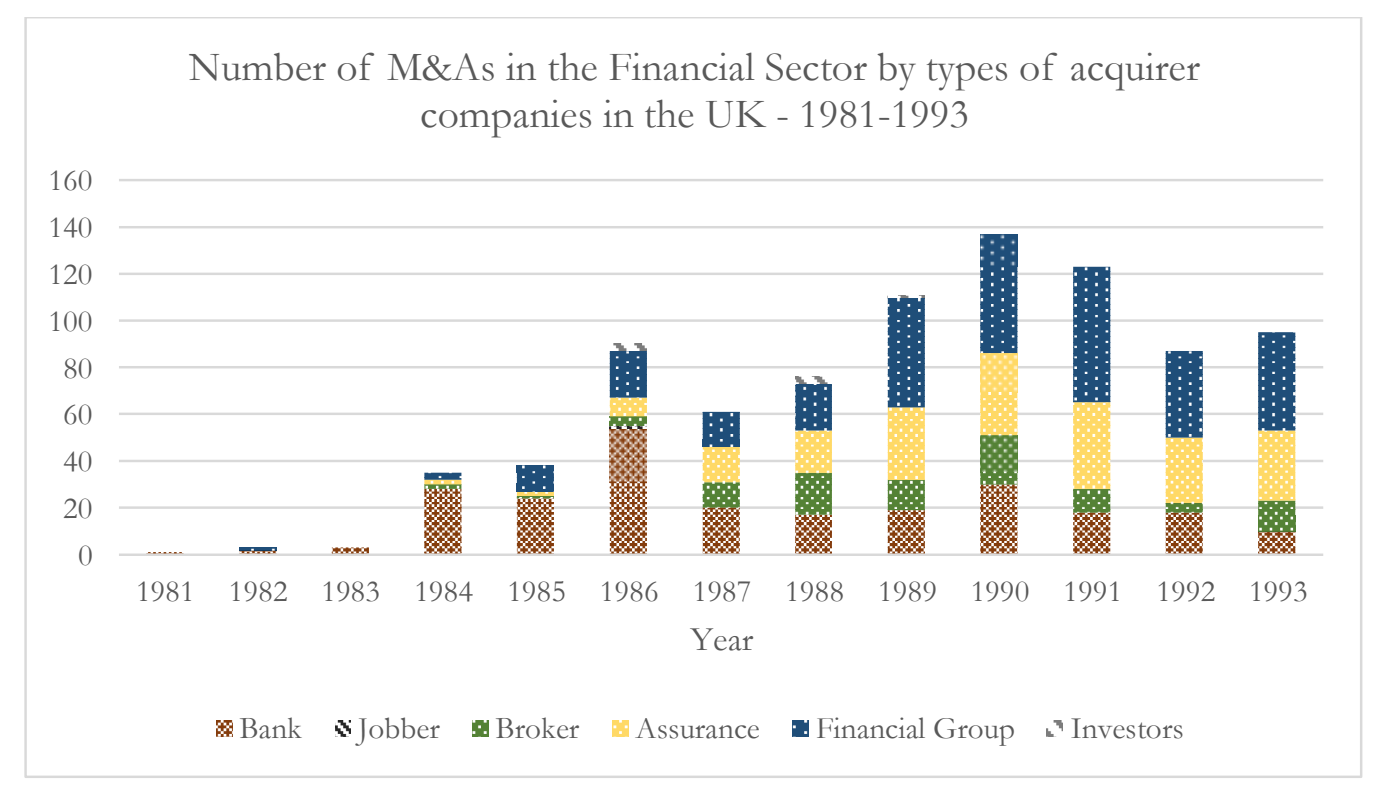

Sources: see Figure 4. 
Figure 6 shows the home countries of acquiring firms from 1981 to 1986 . A major feature was consolidation among British firms which led over half of acquisitions, but American and European companies also swallowed up a significant part of the market.

Figure 6

Nationalities of Acquirer Companies - 01.1981-12.1986

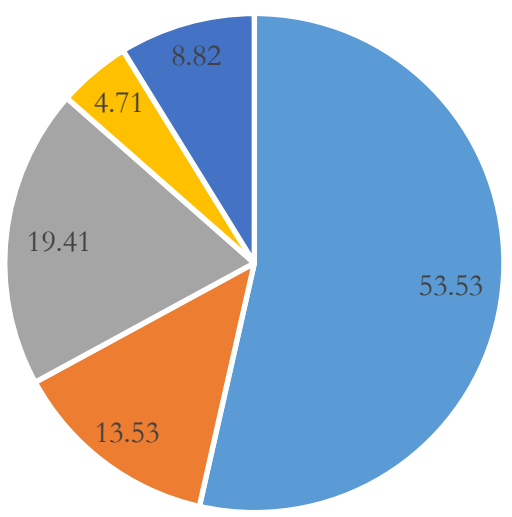

$\square$ British $\backsim$ Europe $\square$ USA $₫$ Various (Investors) $\backsim$ Other Countries

Source: see Figure 4.

The verdict of contemporaries and later historians on the new financial conglomerates in the 1980s is mixed. Thus, Clemons and Weber (1990) concluded that 'mergers led to conflict in style and business culture and to large-scale defections. There appear to be serious difficulties when bankers move into securities broking'. Bellringer and Michie (2014, p. 131) observed that 'What Big Bang had done was to expose the City of London's brokers, dealers and investment bankers to external competition and, even when combined, they lacked the scale, culture and management required to survive'. Perhaps more presciently, a report by G20 central bank governors (BIS 1986) warned that 'how the central banks would respond to the collapse of a major international investment bank that posed a threat of contagion remains to be seen'. Financial conglomerates on an international scale posed huge 
challenges for supervisors who operated mainly on a national basis even after the Basel Accord tried to set minimum international standards for capital adequacy. Cross-border $M \& A$ and the spread of subsidiaries from New York to London blurred the distinctions between London, New York and Frankfurt once industry leaders operated across the three centres by the end of the 1980s.

As important for the LSE as the Big Bang itself was the new IT system, which was rather an afterthought to the changes in the commission rules. The Stock Exchange Automatic Quotation System (SEAQ) launched at the same time as Big Bang but its impact was not completely anticipated. On Big Bang day 28 firms had trading pitches on the floor of the exchange compared with 19 previously, but in the first week only one quarter to one third of trading was on the floor. The floor crowd fell from 1800-2000 people per day to 200-300 a week later. No longer tied to physical trading, banks built their own dealing floors. With the removal of minimum commissions, new business models focused on scale and fee generation through client advising and research. Banks needed larger dealing floors so 'over 70\% of banks who took space in the City in 1985 took in excess of 10,000 square feet' (Lenon, 1987, p. 56). Property developers promised a new venue at Canary Wharf on the River Thames outside the traditional City boundaries that would 'feel like Venice and work like New York'. After a shaky start, this ambitious development became the new financial centre for London.

So what did Big Bang deliver? The number of gilt market makers increased from 3 to 27 and equity turnover increased sharply. As in New York, average commissions fell for large trades of $£ 100,000$ or more while the cost of small trades increased, so individuals were still subsidizing institutional investors (Clemons and Weber, 1990). The number of individual 
share-holders increased, but they owned a declining proportion of total shares: individuals owned $28 \%$ of shares in 1981 but this fell to $21 \%$ by 1989 (ONS). The number of members of the LSE grew once foreign firms were allowed in and so the LSE captured more of the market, but it was also subject to greater regulatory oversight through the 1986 Financial Services Act. Big Bang is not an example of de-regulation; rather self-regulation was continued and accompanied by greater external supervision. Moreover, while the Conservative government may have been a champion of the City, it was not a supporter of the LSE's monopoly, nor a protector of traditional British financial institutions. Many ancient names were gobbled up and disappeared in the run up to Big Bang or shortly afterward. Finally, despite the reforms, London did not close the gap with New York. Although turnover increased after Big Bang, this surge was halted a year later, on Monday 19 October 1987, by a short-term collapse in global share prices. London continued to have higher trading costs than New York (41.2 basis points in 1998 in London compared to 13.4 in the NYSE). ${ }^{20}$ As a result of the competitiveness of the New York exchanges, during the 1980s more European companies chose to list there while the number of American companies listed in European stock markets declined. Figure $x$ shows this trend from 1986-1991 showing that London was the most international of exchanges by home of listed companies until 1990s when the New York exchanges captured many more foreign listings and European exchanges reduced their foreign company listings. For London, as for other exchanges, an important component of this trend was the reduction in US companies listing, which fell in London from 193 in 1986 to 159 in 1991 and 111 by 1997.

${ }^{20}$ Trading costs include commission and fees based on data from 135 institutional investors (Pagano 2002, p. 2671). 
Figure 7

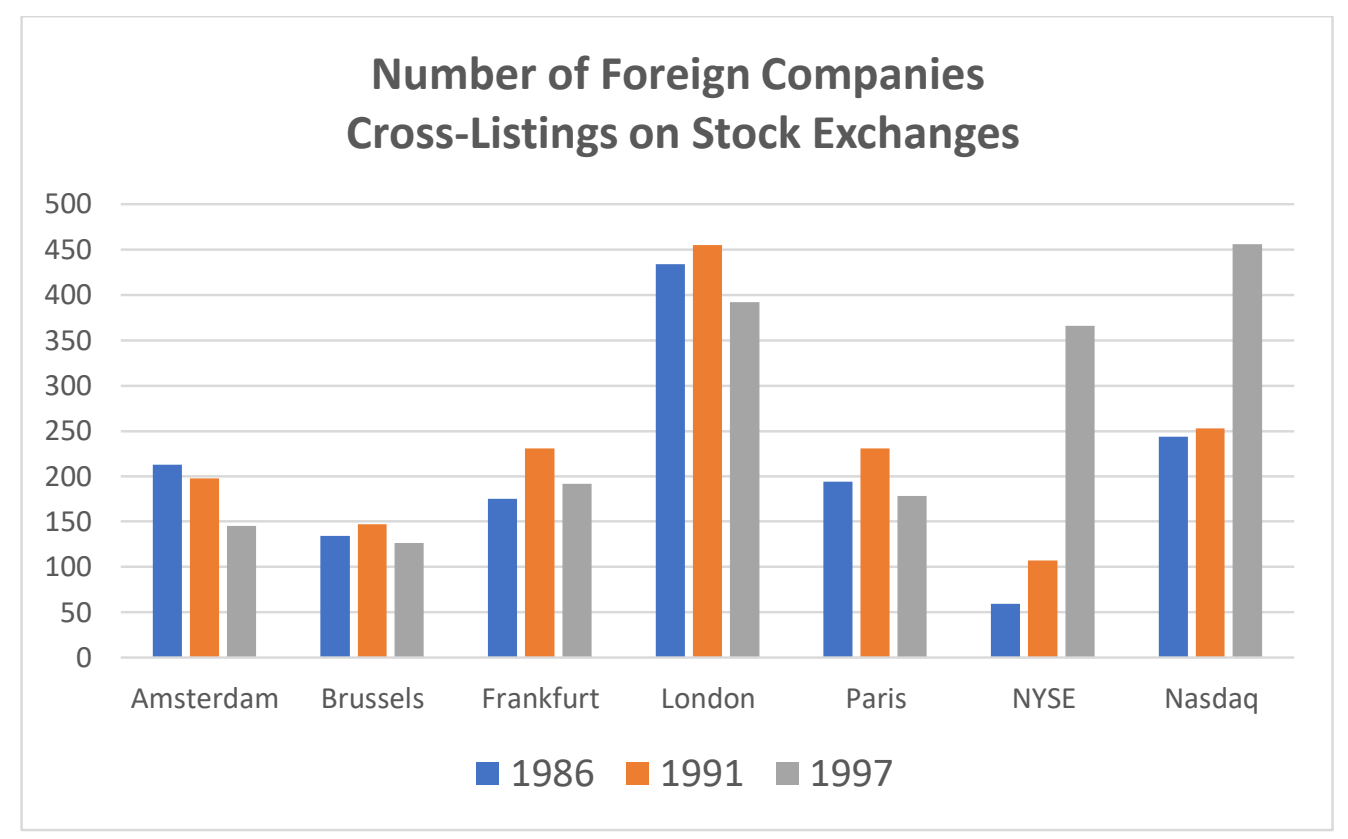

Source: Pagano et al. 2002.

Meanwhile the growth in securities prompted further challenges deregulation of investment banking in the USA.

III

The 1980s was a decade of accelerating deregulation in the USA and changing priorities in Europe. In 1987 the Fed, under its new Chairman Alan Greenspan, allowed bank holding companies to underwrite commercial paper and to trade in municipal bonds. Greenspan came from a Wall Street background and championed its interests. He had been a director of JP Morgan and its banking subsidiary, the Morgan Guaranty Trust Company of New York, for ten years before being appointed as Fed Board Chair. In contrast, his predecessor Paul Volcker had come to the Fed from a career at the Treasury and the New York Federal Reserve Bank rather than the private sector. A month after the October 1987 global stock market crash had required the Fed to support a range of securities companies, Greenspan 
called for the repeal of Glass-Steagall to allow banks to engage in a wider range of securities trading through subsidiaries (Greenspan 1987a). Two weeks later, in December 1987, he described 'the artificial separation of commercial and investment banking' as 'perhaps the single most important anomaly that now plagues our financial system' (Greenspan 1987b). He was supported by the chair of the Senate Banking Committee, William Proxmire, who also sought to overturn Glass-Steagall but faced opposition from the House of Representatives and the securities industry (Nash 1987).

Greenspan's case for removing barriers between investment and commercial banking was two-fold. First, the domestic US securities market had become highly concentrated so that the 'five largest underwriters of commercial paper account for over 90 percent of the market; the five largest underwriters of all domestic corporate debt account for almost 70 percent of the market; and the five largest underwriters of public stock issues account for almost half of the market' (Greenspan 1987a). Secondly, ICT innovation made information processing much easier and decreased the franchise value of banks who relied on their privileged and efficient access to and processing of information to act as financial intermediaries (Greenspan 1988). ${ }^{21}$ Instead, potential creditors had access to information and risk assessment that allowed them to invest directly through commercial paper, mortgage backed securities and other securities rather than through banks. Bank holding companies needed to be able to compete in this direct market in the US in the same way that their foreign subsidiaries were able to underwrite securities and equity in London.

\footnotetext{
${ }^{21}$ Greenspan noted that 'One specialist has estimated that the real cost of recording, transmitting, and processing information has fallen by 95 percent in less than 25 years'.
} 
Despite pressure from the Fed and banks themselves, Congress was not ready to repeal Glass-Steagall so soon after the 1987 stock market crash (and the costly Savings and Loan Crisis earlier in the decade). Instead, piecemeal reforms allowed US banks to underwrite commercial paper and municipal bonds, but the door was starting to open for more diversified holding companies. US bank holding companies were able to invest in foreign banks that blended financial and non-financial business (so-called Edge Act banks) and the Fed's interpretation of Section 20 of Glass Steagall allowed banks to deal in and underwrite securities through subsidiaries so long as they were not 'primarily engaged' in this business. Even before the formal repeal of Glass-Steagall in 1999, therefore, the combination of May Day in New York and Big Bang in London, along with the surge in corporate bond markets and commercial paper, had increased the opportunities for financial conglomerates. The culture of investment banking was changing dramatically.

Hansen has argued that eras of financialization have been followed by periods of social instability as well as financial crisis in the 1930 s and the 2000 s, which points to the need for financialization itself to be understood as cultural and social phenomena as well as economic (Hansen 2014). Certainly, there were clearly identified cultural understandings of financial systems already in the 1960 s and 1970s. The distinctive market-based structures in London and New York were identified as 'Anglo-Saxon' by continental European observers in universal-bank dominated systems (Cassis, 2006, p. 258). Capital markets, and therefore investment banking, were more dominant in the US and the UK, compared with bank loan dominated credit in, for example, West Germany. Different liquidity preferences were also important in distinguishing English banks from continental German banks with longer time horizons (Schneider-Lenne 1993, Balia and Polak 2004). 
These cultural identities had traction in the public discourse, but as Berghoff (2016) has argued, the distinctions between the US and German institutional structures of capitalism became apparent only in the post-1945 era rather than tracing back to the origins of each country's financial sector. Any link to what might be considered 'Anglo-Saxon' culture in the $5^{\text {th }}$ century is extremely remote. Fohlin has pointed out that in the late $19^{\text {th }}$ and early $20^{\text {th }}$ century, JP Morgan in the US was 'perhaps acting even more like the stylized view of a German universal banker than the Germans ever did' (Fohlin 2016, p. 152). Nevertheless, the term Anglo-Saxon became widely used in reference to American and British financial systems to reflect market-based rather than bank-based credit.

Despite the vague nature of the definition, becoming more 'Anglo-Saxon' became an imperative for European banks to be able to compete and survive in the new business environment of the 1980s. By this they meant changing their strategies to focus more on international investment banking, particularly securities trading, corporate finance, M\&A, fund management and equities. Perhaps the most obvious case was Deutsche Bank, the quintessential German universal bank. In the mid-1980s the charismatic head of Deutsche Bank, Alfred Herrhausen, launched a campaign to enhance the bank's global and domestic competitiveness by acquiring greater expertise and market share in international investment banking. Without a native pool of such expertise in Germany, this required cooperating with an existing 'Anglo-Saxon' institution, in this case Morgan Grenfell in the City of London, taken over in 1989. Thus began Deutsche Bank's ultimately pyrrhic ambition to compete with the large American universal investment banks (Schenk 2020b). Deutsche Bank's investment banking activities drew the bank into a series of scandals and financial losses revealed after 2010, which caused the share price to plummet and in July 2019 the 
bank announced that it would dramatically scale back this part of its business with a loss of 20,000 jobs.

From the start, Cassis' research has sought to investigate the structural and cultural aspects of international financial centres with particular attention to the role of financial elites and the interaction between the market and regulators. He has also provided the careful historian's perspective that identifies continuities as well as ruptures. The globalisation of the 1980s has been viewed by many as a rupture, but examined more closely it is clear that there were important foundations laid in the 1970s that underpinned the way markets operated.

In terms of the interaction between markets and regulators, legal constraints in New York and Frankfurt in the 1970s operated to the advantage of London as an international financial centre but not to the advantage of British financial institutions. The elimination of fixed commission in New York and London has shown how different institutional contexts influenced the outcome of a regulatory change. In the M\&A wave that followed, US regulation created barriers to entry for foreign firms into investment banking (despite the Edge Act and Section 20 loopholes) while the IBF in 1981 fostered a greater share of cross-border banking for American institutions. The New York experience, therefore, consolidated rather than challenged the control of domestic institutions.

In contrast when London followed with Big Bang over a decade later, similar results for customers and for consolidation of the industry ensued but rather than fostering British institutions, this process increased the international flavour of investment banking in The City. During the second globalisation, the links between New York and London were enhanced both by mergers and acquisitions of securities companies as well as the spread of American Edge 
Act and European banks into London. Despite the huge surge in the US credit market in the 1980s, the City of London remained the leading centre for international banking. It was in this context that Cassis published his first in-depth historical treatment of the City of London in his career-long exploration of international financial centres (Cassis 1984). The legacy of his historical approach to the development of global financial capitalism continues to inspire and inform. 


\section{References}

AUGAR, P (2000). The Death of Gentlemanly Capitalism: the rise and fall of London's investment banks. London: Penguin.

BALIA, S. and POLAK, B. (2004). The emergence and persistence of the Anglo-Saxon and German financial systems. The Review of Financial Studies, 17(1), pp.129-163.

BANK FOR INTERNATIONAL SETTLEMENTS (1986). Recent innovations in international banking, Prepared by a Study Group established by the Central Banks of the Group of Ten Countries, Bank for International Settlements.

BASKIN, J. and MIRANTI, P. (1997). A History of Corporate Finance. Cambridge: Cambridge University Press.

BATTILOSSI, S. (2002). Banking with multinationals: British clearing banks and the Euromarkets' challenge, 1958-76. In S. BATTILOSSI and Y. CASSIS (eds.), European Banks and the American Challenge: Competition and Cooperation in International Banking under Bretton Woods. Oxford: Oxford University Press, pp. 103-34.

BELLRINGER, C. and MICHIE, R. (2014). Big Bang in the City of London: an intentional revolution or an accident? Financial History Review, 21(2), pp. 111-137.

BERGHOFF, H. (2016). Varieties of financialization? Evidence from German industry in the 1990s. Business History Review, 90(1), pp. 81-108.

BILLINGS, M. and WILSON, J. (2019). "Breaking New Ground": The National Enterprise Board, Ferranti, and Britain's prehistory of privatization. Enterprise and Society, 20(4), pp. 907-938.

BORDO, M. and JAMES, H. (2019). The trade-offs between macroeconomics, political economy and international relations. Financial History Review, 26(3), pp. 247-266.

BURK, K. (1989). Morgan Grenfell 1838-1988: The Biography of a Merchant Bank. Oxford: Oxford University Press.

BURK, K. (1998). Deutsche Bank: from entry to embrace 1983-1994, in M. POHL and K. BURK, Deutsche Bank in London 1873-1998. Munich: Piper

BUSCHGEN, H.E. (1995). Deutsche Bank from 1957 to the Present: the emergence of an international financial conglomerate. In L. GALL, G.D. FELDMAN, H. JAMES, C-L. HOLTFRERICH 
and H.E. BUSCHGEN, The Deutsche Bank 1870-1995. London: Weidenfeld and Nicolson, pp. 523-796.

CAPIE, F. (2010) The Bank of England 1950s to 1979. Cambridge: Cambridge University Press.

CASSIS, Y. (1984) Les Banquiers de la City a l'epoque Edouardienne. Geneva: Libraire Droz, 1984 [English translation: Y. Cassis, City Bankers, 1890-1914. Cambridge: Cambridge University Press, 1994.]

CASSIS, Y. (1991) (ed.). Finance and Financiers in European History 1880-1960, Cambridge: Cambridge University Press.

CASSIS, Y. (2002). Before the storm: European banks in the 1950s. In S. BATTILOSSI and Y. CASSIS (eds.), European Banks and the American Challenge: competition and cooperation in international banking under Bretton Woods. Oxford: Oxford University Press.

CASSIS, Y. and TELESCA, G. (2018) (eds.). Financial Elites and European Banking: Historical Perspectives. Oxford: Oxford University Press.

CASSIS, Y. (2006). Capitals of Capital. A History of International Financial Centres, 1780-2005. Cambridge: Cambridge University Press.

CLEMONS, E.K. and WEBER, B.W. (1990). London Big Bang: a case study of information technology, competitive impact and organizational change. Journal of Management Information Systems, 6(4), p.41-60.

DAVIS, G.F. and KIM, S. (2015). Financialization of the economy. Annual Review of Sociology, 41, 203-21.

EDWARDS, A. (2016). 'Manufacturing Capitalists': The Wider Share Ownership Council and the problem of 'Popular Capitalism', 1958-92. Twentieth Century British History, 27(1), Pp. 100-123.

EPSTEIN G. (2005). Financialization and the World Economy. Cheltenham, UK: Edward Elgar. EPSTEIN, G. (2018). On the social efficiency of finance. Development and Change, 49(2), 2018, pp. 330-352. 
FOHLIN, C. (2016). A brief history of investment banking from medieval times to the present. In Y. CASSIS, C. SCHENK and R. GROSSMAN (eds.), Oxford Handbook of Banking and Financial History. Oxford: Oxford University Press.

GOODHART, C. (2011). The Basel Committee on Banking Supervision: A History of the Early Years 1974-1997. Cambridge: Cambridge University Press.

GREENSPAN, A. (1987a). Testimony before the Committee on Financial Institutions Supervision, Regulation \& Insurance, Committee on Banking, Finance \& Urban Affairs, US House of Representatives, 18 November.

GREENSPAN, A. (1987b). Testimony before Committee on Banking, Housing and Urban Affairs, US Senate, 1 December.

GREENSPAN, A. (1988). An Overview of Financial Restructuring : Remarks before the Conference on Bank Structure and Competition, Federal Reserve Bank of Chicago, May 12.

HANSEN, P. (2014). From finance capitalism to financialization: A cultural and narrative perspective on 150 Years of financial history. Enterprise and Society, 15(4), pp. 605-642.

HAYES, A. H. (1971). The 1970 Amendments to the Bank Holding Company Act:

opportunities to diversify, speech before the New York State Bankers Association, 25 January 1971, Reserve Bank of New York Monthly Bulletin, pp. 23-27.

HELLEINER, E. (1994). The world of money: the political economy of international capital mobility. Policy Sciences, 27, pp. 295-98.

JEFFERIS, R.H. (1990). The high yield debt market 1980-1990. Federal Reserve Bank of Cleveland Economic Commentary, 1 April.

JOHNSON, C.J. and MCLAUGHLIN, J. (2006). Corporate Finance and the Securities Laws. New York: Aspen

JORDEN, J.F. (1975). "Paying up" for research: a regulatory and legislative analysis. Duke Law Journal, n. 5, pp. 1103-1129.

KRIPPNER, G.R. (2011). Capitalizing on Crisis: The Political Origins of the Rise of Finance. Harvard: Harvard University Press.

KYNASTON, D. (2011). City of London: the history. London: Chatto and Windus. 
LAWSON, N. (2006). Forward. In Big Bang 20 Years On: New Challenges Facing the Financial Services Sector. London: Centre for Policy Studies, London, pp. i-v

LENON, B. (1987). The geography of the Big Bang: London's office building boom. Geography: Journal of the Geographical Association 72, Iss. 1: 56-59.

LIN, K-H and TOMASKOVIC-DEVEY, D. (2013). Financialization and U.S. income inequality, 1970-2008. American Journal of Sociology, 118(5), pp.1284-1329.

LOOMIS, P.A. (1975). Speech to Financial Analysis Federation Annual Conference, Chicago Illinois, 3 June 1975.

MACKENZIE, D. (2004). The big, bad wolf and the rational market: portfolio insurance, the 1987 crash and the performativity of economics. Economy and Society, 33:3, pp. 303-334.

MCCAULEY, R.N., RUUD, J.S. and IACONO, F., (1999). Dodging Bullets: Changing US Corporate Capital in the 1980s and 1990s. Cambridge, MA: MIT Press.

MICHIE, R. (1999) The London Stock Exchange: a history. Oxford: Oxford University Press. MORAN, M. (1986). The Politics of Banking: The Strange Case of Competition and Credit Control. Basingstoke: Palgrave Macmillan.

NASH, N.C. (1987). 'Let banks enter securities field, Greenspan says', New York Times, 19 November.

NEEDHAM, D. (2014) UK Monetary Policy from Devaluation to Thatcher, 1967-82.

Basingstoke: Palgrave Macmillan.

OFFICE OF NATIONAL STATISTICS, Ownership of UK Quoted Shares.

https://www.ons.gov.uk/economy/investmentspensionsandtrusts/bulletins/ownershipofuk quotedshares/2018

PAGANO, M., ROELL, A.A. and ZECHNER, J. (2002). The geography of equity listing: Why do companies list abroad? Journal of Finance 57(6), pp. 2651-2694.

PALAN, R., MURPHY, R. and CHAVAGNEUX, C. (2013). Tax Havens: how globalization really works. Ithaca, N.Y.: Cornell University Press.

REID, M. (1982). The Secondary Banking Crisis 1973-75: its causes and course. Basingstoke: Palgrave Macmillan. 
RHOADES, S.A. (1983). Concentration of world banking and the role of U.S. banks among the 100 largest, 1956-1980. Journal of Banking and Finance, 7, pp. 427-437.

ROBINSON, W.I. (2004). A theory of Global Capitalism: Production, Class and State in a Transnational World. Baltimore: Johns Hopkins University Press.

RODRIK, D. (2011). The Globalisation Paradox: Why Global Markets, States, and Democracy Can't Coexist. Oxford: Oxford University Press.

ROY, R and T. WILLETT (2018). Financialization, in M. JUERGENSMEYER, S. SASSEN, M. B. STEGER, and V. FAESSEL (eds), The Oxford Handbook of Global Studies, Oxford: Oxford University Press

SCHENK, C.R. (2002). International financial centres, 1958-1971: competitiveness and complementarity. In S. BATTILOSSI and Y. CASSIS (eds.) European Banks and the American Challenge: Competition and Cooperation in International Banking under Bretton Woods. Oxford University Press, pp. 74-102.

SCHENK, C.R. (2017). Rogue trading at Lloyds Bank International, 1974: Operational risk in volatile markets, Business History Review, 91, pp. 105-128.

SCHENK, C.R. (2020a). The origins of the Asia Dollar Market 1968-1986: Regulatory competition and complementarity in Singapore and Hong Kong. Financial History Review, 27(1), pp. 17-44.

SCHENK, C.R. (2020b) Globalisation and crisis. In W. PLUMPE, A. NUTZENADEL, C.R. SCHENK, Deutsche Bank: Global Hausbank, 1870-2020. London: Bloomsbury.

SCHNEIDER-LENNE, E. (1993). 'The Governance of Good Business'. Business Strategy Review, March, p. 75-85.

SECURITIES AND EXCHANGE COMMISSION (1975). Annual Report.

SECURITIES AND EXCHANGE COMMISSION (1974). Annual Report.

STRANGE, S. (1986) Casino Capitalism. London: Blackwells.

WALTER, I. (2004). Mergers and Acquisitions in Banking and Finance: What Works, What Fails and Why? Oxford: Oxford University Press.

WAYNE, L. (1985) Is Wall Street ready for May Day 2?, New York Times, 28 April 1985. 